\title{
Open and Distance Learning Education Its Scope and Constraints in Indian Scenario
}

\author{
Dr. Santi Kundu, \\ Department of Chemistry, Nistarini College, Purulia, INDIA
}

\begin{abstract}
Open and Distance Learning system of education had grown tremendously around the world by 1960. It was started also in India in the form of correspondence course or distance education by some traditional Universities like Delhi University (since 1962). The system was encouraged in early eighties when Union Government passed a bill to establish a central University in the name of former Prime Minister Indira Gandhi in 1985. The Distance Education Council (DEC) was also set up under the same Act to coordinate among the distance learning institute and maintain standard of education on the all India level. Since then $O D L$ system is doing well under the leadership of the central Open University IGNOU. In a developing country like India many real problems arise in implementing Government policy. However, sorting out of problems and discovering probable solutions are also done continuously. This paper is dealing with the benefits, success, drawbacks and some suggestions to overcome the present problems faced by ODL system in India.
\end{abstract}

Keywords: About five key words in alphabetical order, separated by comma

\section{Introduction}

In order to meet challenges of access and equity to higher education for large segments of the population, and in particular, the disadvantaged groups such as those living in remote and rural areas including working people, housewives and other adults who wish to upgrade or acquire knowledge through studies in various fields, academic institutions and government sector were looking for an alternative system of education that can provide access to learning of information as well as a degree for recognition like traditional system of education. On March 20, 1728 there was an advertisement in the Boston Gazette by "Caleb Phillips", a teacher of the new method of short hand ${ }^{1}$. The statement of the advertisement was "persons in the Country desirous to learn this Art, may by having the several lessons sent weekly to them, be as perfectly instructed as those that live in Boston." This advertisement showed that communication via mailing system can be used to spread education to the learners when the source of information is separated by time and distance or both ${ }^{2}$. This kind of educational system which is open to all is called Open and Distance Learning (ODL) educational system. The first university in the world that started to offer distance learning degree, establishing its 'External Programme' in 1858, was The University of London ${ }^{3}$. To provide opportunities of higher education to all sections of the society and catering to the changing individual and social needs in India, the State Govt. of Andhra Pradesh for the first time established the 'Andhra Pradesh Open University' on 26 August 1982 through APOU Act 1982. This University was renamed as Dr. B.R. Ambedkar Open University on $7^{\text {th }}$ December 1991 by the Government of Andhra Pradesh (APOU Act, 1992). In 1985, the Union Government took initiative for establishment of a National Open University and on $20^{\text {th }}$ September 1985, Indira Gandhi National Open University (IGNOU) came into existence. Apart from the above two open universities, we have another 12 State Open Universities and 140 dual universities offering programmes /courses through the distance mode. Thus about $40 \%$ universities in India are offering D.E. To maintain educational standard and strong co-ordination among all ODL institute, Distance Education Council (DEC), was established in 1991 under section 16(7) read with Section 5(2) of the IGNOU Act, 1985. Since then DEC, as an apex agency, was responsible for recognizing ODL institutions in India. It was mandatory for all institutions to seek prior approval of the DEC for all existing and new programmes offered through distance mode. From $4^{\text {th }}$ May 2013, IGNOU through a notification repealed and deleted the statute that provisioned for the DEC. From this time UGC has become a regulatory authority for higher education through open and distance learning mode (ODL). As a result, instead of requiring DEC recognition, approval of UGC will be required now. The Open Universities which are already recognized by DEC are expected to follow the same guidelines as given by DEC. This paper is mainly focusing on the benefits and drawbacks of the ODL system under the apex of DEC. Discussions and suggestions to minimize the constraints and hence to increase success rate will be given at the end. 


\section{Scope Of Odl System:}

University Grants Commission (UGC) has set the target of enhancing the gross enrolment ratio in higher education from the present $11 \%$ to $21 \%$ by 2015 . To achieve this difficult target Govt. of India is considering ODL system as alternative model with special emphasis from the $10^{\text {th }} \mathrm{Plan}$. ODL system is the only system that can reach the door step of every section of the society irrespective of class, creed, gender, race and geographic location.

The characteristic features which make the system so important are:

II.1) Flexibility:

The system is flexible in regard to modalities, timing, pace, place, age, admission criteria etc ${ }^{4}$. Learners who are not able to continue their education through traditional system due to socio-economic or cultural reason are getting opportunities here. Flexibility in age and qualification to enter in desired academic programs makes the system learners friendly. Here students are free to choose the subject of studies according their interest. Use of satellite, e-books/journals, audio-visual system in teaching learning process helps the learner to study their course materials in their own space and place. Again for better understanding, learners can attend counseling or personal contact program (PCP) in the nearby study centre during weekends/holidays.

\section{II.2) Cost Effective:}

Expenditure for higher education in the traditional system, both for public and private institutes, is very high. Education through distance mode is able to help the students by saving considerable amount of money by removing the cost of transportation and high-priced printed text books of high $\operatorname{cost}^{5}$. As the teaching learning process in this system adopts multimedia approach, students can avail digital study materials for a reduced price. Radio and television programmes also helps them to take classes at their own places. Apart from this, the system also permits learning while earning.

\section{II.3) Learning satisfaction:}

Unlike traditional system, students of ODL system attend online classes individually without any disturbance from others. When difficulties arise students review their lessons more than once and solve the problem. Students can also manipulate the coursework to fit their learning by focusing more on their weaker topics ${ }^{6}$. In this way students can build self confidence and get higher satisfaction with their learning experiences. A survey report reveals that the technique is very much fruitful for the students enrolled for healthcare or mental health distance learning program ${ }^{7}$.

II.4) Equal access:

In the traditional system, students of a certain age group are allowed. Again, for SC, ST and Physically Challenged students some reservation is there. It is very difficult for Trans-Genders to take education in the traditional system. Peoples who are in jail are unable to obtain any degrees through traditional system. Distance education may provide equal access irrespective of socioeconomic status, gender, race, age, or cost per student.

II.5) Dual degree:

While studying under traditional system a student can simultaneously enroll for a degree of the same level in Open University. In such case credit transfer will be given due consideration through a MOU between Open University and the respective University.

\section{II.6) Migration Problem:}

Students taking admission for Masters degree in Open University do not need any migration from previous university where he/she obtained Bachelor degree. However, when a student graduated from Open University takes admission for Masters degree in a traditional university he/she needs migration.

\section{II.7) Assignment Marks:}

Apart from contact session or PCP there is also a provision of assignment in ODL system. Students are asked to collect question papers from study centers or directly from homepage of the respective Open University. Afterwards they submit the answer scripts in a limited time frame. This is then evaluated by subject expert and given back to the students for checking their mistake. Writing of assignment is must for the students willing to sit in the forth coming examination. $20 \%$ of assignment marks and $80 \%$ of the marks obtained in Term-End-Examination is added to make the total. This kind of marks distribution directly helps distance learners to secure pass marks. 


\section{Constraints To Odl System:}

Since 1980, Open and Distance Learning educational methodology has been extensively used in India. Now it is evident that Open University Education in India is playing a vital role in respect of huge number of enrolled students in higher education from disadvantaged group of the society. However, different survey reports reveal that the number of students completing higher education with adequate quality is not satisfactory 7-9. To improve the quality Govt. has changed education policy time to time. However, simultaneous improvement in quality and quantity will not be possible unless we consider the following real problems before implementing any education policy/ technique.

III.1) Lack of knowledge in using technology:

With the progress of time technology for communication system is being developed and ODL system is adopting this. However, students especially from rural area are enrolling in ODL system without proper training of the tools to be used for successful program. These students, due to lack of technology skills, mostly become unsuccessful or drop outs.

\section{III.2) Vast curriculum area:}

Online courses are normally not restricted to an upper size. As a result traditional teaching method cannot be applied here. Both teachers and students face problems.

\section{III.3) Lack of sufficient infrastructure}

Distance learning program is quite new and it does not have sufficient infrastructure and learning environment like traditional system. For this reason instructors are facing problems in organizing and planning distance learning programmes, especially for new courses.

III. 4) Scarcity of counselors near study center:

Although care has been taken in opening study centers near the door steps of learners, the availability of skilled and knowledgeable counselors near the study center is not checked in most cases. As a result study centers as well as the learners are facing difficulties.

\section{5) Hidden Cost:}

For online learning, students need training to use technology. They must have their own or rented computer and internet connection. Again if they want hard copy of any study materials downloaded from web site extra cost has to be paid. To attend live video program they have to do proper time management. When contact programs are not arranged nearby or become obscure then learners look for private coaching, paying extra money.

III. 6) Unavailability of desired course in nearby study center:

There is a difficulty to run practical based subjects in Open Education as it needs permanent Laboratory set up. Again there are some courses like nursing, clinical which are not available through distance learning. Thus distance learning is not suited for all subjects.

III.7) Lack of oral communication skill:

Distance learners do not get opportunity to interact with their classmates and with the professors like traditional system. Hence their oral communication and presentation skills do not develop properly.

\section{Discussions And Suggestions:}

Distance learning degree, began to be offered in the world by the University of London in the year 1858. However, the Union Govt. of India had considered this methodology only after 126 years and established a Central Open University in the name of former Prime Minister Indira Gandhi in the year of 1985. Within 28 years IGNOU has proved its potentiality, securing number one position in enrolment in the world. This university offers 310 degree programmes in arts, science, commerce, social sciences and information technology through different Schools in 36 countries around the world. Now this university is considered to be the world leader in distance education. This is one of the best achievements of the Indian ODL system. The list of achievements of Indian ODL system has also been enriched by the contribution of Yashwantrao Chavan Maharashtra Open University (YCMOU) established in July 1989 in Nashik, Maharashtra. This university has been conferred 'Award of Excellence for Institutional Achievement' for the year 2002 by Commonwealth of Learning (COL)' Canada. Netaji Subhas Open University (NSOU) founded in the year of 1997 in West Bengal, has been conferred Excellence in Distance Education Award (EDEA) from the Commonwealth of Learning (COL) in the year 2006 for its brilliant academic performances. 
This university has achieved the status of 'Mega University' with enrolment over 250,000 students. Apart from Bachelor, and Master / Post graduate degree, Indian Open system also offers Diploma, Advanced Diploma, Certificate, MBA and Ph.D. in different fields of education.

Apart from Open Universities, enrolment through Dual mode Universities is also increasing rapidly. Traditional Universities which offer distance learning program by establishing Distance Education Institutions (DEI) and / or Correspondence Courses Institutes (CCIs) along their regular campus based program are known as Dual Universities. At present total enrolments in dual mode universities are much higher than enrolment in Open Universities. Leading role is playing by Delhi University (1962), Mumbai University, Annamalai University, Acharya Nagarjuna University etc. Another channel of enrolment in higher education is Mixed Mode Universities. Although their number is limited but they exist and impart education in a wide variety of mode. Amity University and Lovely Professional University (LPU) are examples.

From above discussion it is very clear that the target of enhancing the gross enrolment ratio in higher education from present $11 \%$ to $21 \%$ by 2015 as set by UGC will be fulfilled easily if Indian ODL system of education is applied and handled with care. To do so following suggestions can be considered.

IV. 1) To manage technology barriers, distance learners must have training on each tool to be used throughout the program in advance. This can be done by incorporating a proactive policy for managing technology barriers in school level.

IV.2) The results of a study of Washington state community college students showed that distance learning students tended to drop out more often than their traditional counterparts due to difficulties in language and time management. This problem is also here in India. Most of the learners like to study in their own mother tongue. To solve this problem we can open at least one State Open University in every State and Territory allowing them to offer education in regional language.

IV.3) All the CCIs and private initiatives may be converted to study centers of the respective State Open Universities (SOU).

IV.4) To maintain standard and equal syllabus in the all-India level IGNOU may play the following roles -

IV.4.1) Can arrange training program for course writer, Coordinator, Counselors and others associated with DLearning system.

IV.4.2) Can establish resource center like studio for video/audio production.

IV .4.3) Can establish regional library with a rich collection of books and journals on distance education.

IV.4.4) Can prepare instructional material for some of the innovative program and making them available for translation in regional language.

IV.4.5) Although negligible but still there are some employers who do not acknowledge distance learning degree. This problem can be solved by discussion between employers and distance learning institutions in presence of IGNOU before designing curriculum.

IV.4.6) Distance learners normally study alone and miss social physical interaction and the scope of personality development. They also do not get the chance to participate in extracurricular activities like NSS, NCC etc. Video conference, e-mail, chats etc. are not sufficient to give that smell. In this case we can incorporate such auxiliary program like NSS, NCC so that learners of same class and counselors can come at least once in a month to their nearby study centre and mixed together.

IV.4.7) To encourage economically poor section of the society we may think for fee concession (half-free or full-free) or can help them in the form of stipend / scholarship on the basis of their first semester result.

IV.4.8) In a survey on UK made by Werry it reveals that every respectable person of the society admits that the distance learners are as good as traditional learners. But there are still some people who believe that face-to-face interaction as we have from the GURUKUL system can only produce better scholar. Werry did not sort out any solution but wrote that it is an emotional problem and this will go with time.

\section{Conclusion:}

In conclusion, it can be said that the Distance Learning system of education is being more popular around the world and in India day by day. Central Open University of India IGNOU by name is securing top position enrolling 7000 students per year from 36 countries around the world. Use of updated communication technology is making the methodology more attractive to the learners. In spite of its remarkable success, one can still find some constraints in this learning system. To remove these constraints probable suggestions are given. It has been suggested that Government should think such policy which will be able to remove technophobia from all students in school level. Suggestions are also given to open at least one State Open University through which learners can study in their own language. To encourage economically poor students, suggestions are given to arrange for financial help in the form of stipend / fee concession or one time gift to the students performing good result in the $1^{\text {st }}$ semester. Finally to develop personality of distance learners it has been suggested to incorporate programs like NSS, NCC etc. 


\section{Acknowledgements}

Thanks to the authority of Nistarini College for providing me opportunity to act as Asstt. Coordinator in their NSOU study center.

\section{References}

[1]. Holmberg, Börje (2005), The evolution, principles and practices of distance education Studien und Berichte der Arbeitsstel Fernstudienforschung der Carl von Ossietzky Universität Oldenburg [ASF] (in German) 11. Bibliotheks-und Informationssystem der Universitat Oldenburg. p. 13. Retrieved 23 January 2011. ISBN 3-8142-0933-8

[2]. Honeyman, M; Miller, G (December 1993). "Agriculture distance education: A valid alternative for higher education?". Proceedings of the 20th Annual National Agricultural Education Research Meeting: 67-73.

[3]. "Key Facts", External Programme, University of London

[4]. Oblinger, Diana G. (2000). "The Nature and Purpose of Distance Education" The Technology Source (Michigan: Michigan Virtual University) (March/April). Retrieved 23 January 2011.

[5]. "Benefits of Online Education". Worldwidelearn.com. Retrieved 2013-04-01.

[6]. Kirtman, Lisa (Fall 2009). "Online Versus In-Class Courses: An Examination of Differences in Learning Outcomes". Issues in Teacher Education 18 (2): 103-115. Retrieved 30 March 2013.

[7]. Stanton, S. (2001). Going the distance; Developing shared web-based learning programmes. Occupational Therapy International, 8(2), 96-106

[8]. Daniel, Sir John 2005: Towards a Culture of Quality. (International Conference of Quality in Distance Education, Netaji Subhash Chandra Bose Open University, Kolkata

[9]. Daniel, Sir John and Kanwar Asha 2006: Quality Assurance for Open, Distance and e- earning (World Bank Seminar) 